Journal homepage: http://www.journalijar.com

Journal DOI: $\underline{\text { 10.21474/IJAR01 }}$

RESEARCH ARTICLE
INTERNATIONAL JOURNAL

OF ADVANCED RESEARCH

\title{
A COMPARATIVE STUDY OF HOME-BASED VERSUS OUT-OF HOME MUMPRENEURSHIP VENTURES CHALLENGES IN BOTSWANA.
}

\section{Clever Gumbo and Sametsi Ditshupo.}

Botho University, Faculty of Business and Accounting, P.O. Box 501564 Gaborone Botswana.

\section{Manuscript Info}

\section{Manuscript History:}

Received: 25 April 2016

Final Accepted: 19 May 2016

Published Online: June 2016

Key words:

Mumpreneurship;

Mumpreneurs; Business

challenges, Home based

businesses; Out-of home

businesses.

*Corresponding Author

Clever Gumbo.

\section{Abstract}

The purpose of this paper is to present empirical research done on Botswana women in business (mumpreneurs). An increase in women's educational levels, and decline in men's earnings are some of the factors that have contributed to the surge of women in the workforce (formal or informal). Mumpreneurs are female business owners who actively balance the role of mum and the role of entrepreneur. Botswana mumpreneurs possess some commonly observed qualities that can, and often do enhance their competitiveness: they can identify viable business ideas, run the business with determination, and streamline processes efficiently. We adopted a qualitative research in which data was collected from 13 selected mumpreneurs through semi structured interviews. Our findings established that both home based and out of home Botswana mumpreneurs encounter five main challenges: business environment, government and institutional, societal (society, self, family), financial and ethical challenges. Basing on our findings, we suggest possible strategies for the enhancement and sustainability of businesses run by mumpreneurs.

Copy Right, IJAR, 2016, All rights reserved.

\section{Introduction:-}

An entrepreneur is a founder of a new business or person who started a new business where there was none before (Hani et al., 2012). Entrepreneurship is the process of starting a business and successfully managing that business (Hani et al., 2012). An entrepreneur perceives an opportunity and exhibits potential to exploit the opportunity (Hani et al., 2012). According to Schumpeter (1934), entrepreneurship, whether run by men or women, results in new industries and in new combination of currently existing inputs. An entrepreneur is an individual who organizes or operates a business or businesses (Hani et al., 2012).Global Entrepreneurship Monitor (GEM) (2007) identified that women signify more than a third of all entrepreneurs in the world (Nel, Maritz \& Thongprovati, 2010). A woman's decision to be an entrepreneur has a positive implication as it provides an empowering choice that grants an alternative to careers within male dominated organisations and offers greater flexibility, opportunities for creativity 
and self fulfillment (Lewis, Harris. Morrison \& Ho, 2015). The Small Medium and Micro Enterprises (SMMEs) category in which most women entrepreneurs operate are observed as the main sources of jobs, they create entrepreneurial spirit and promote innovation not only in developed nations, but more importantly in developing nations (Hani, Rachmania, Setyaningsih \& Putri, 2012). In developing nations like Botswana, women have demonstrated ability to start and successfully run businesses (Hani et al., 2012). Botswana 2011 Population and Housing Census revealed Gaborone population as comprised of: $51 \%$ women and $49 \%$ men, implying that there are more women than men in Botswana (Statistics Botswana, 2013). Mumpreneurs create new business around their family environment (Nel et al., 2010). The convergence of personal and family life in entrepreneurship has permeated discussion on the growing gender and entrepreneurship literature (Harris, Morrison, Ho \& Lewis, 2008), hence the motive for these researchers to undertake this kind of research.

There has been an increase in the number of women entrepreneurs throughout the world who participate in early stage entrepreneurial activity and establish themselves as owners (GEM, 2007). Over 75\% of SMMEs operating in Botswana are women owned (Modisane, ny).Women businesses are represented in all Botswana economic sectors that includes catering, transport, manufacturing, supplies companies (Modisane, ny). GEM (2007) affirmed that women in entrepreneurial activity gain higher profits than men and this suggests that women have a greater sense of leadership characterized by better governance and management practices (Allen, Elam, Langowitz \& Dean, 2007). Mumpreneurs are a group of entrepreneurs who deserve special attention as they are perceived to be breaking a new ground in their business practices by redefining their entrepreneurial identities as those who attempt to find congruence between their role as "good mothers" and "good business women" (Ekinsmyth, 2011).

During the last decade, the number of Batswana women who were engaged in business has been observed to have increased significantly (Hani et al., 2012). The emergence of the concept "mumpreneurs" which describes mothers who start and manage business ventures, has led to many mothers owned ventures being established (Nel et al., 2010). Women entrepreneurs play a significant role in contributing to the growth of Botswana economy and the general global economies (Nel et al., 2010). The uniqueness of mumpreneurs is mainly about balancing work and life, getting a sense of satisfaction with oneself, financial independence, gaining respect to equalise gender imbalances (Nel et al., 2010). The aspect of balancing work and life enshrined in mumpreneurship brings about diverse challenges that tempted these researchers to undertake this research. It is within view that this study was meant to investigate challenges that are encountered by home based and out of home mumpreneurs. This paper is comprised of: background of Botswana, literature review, method, findings, and possible strategies for mumpreneurship growth, conclusions, and possible areas of future research.

\section{Background of Botswana:-}

Botswana is a small country in the southern part of Africa with an estimated population of 2.1million in 2011 census (Statistics Botswana, 2013). Poverty is high among Botswana women headed households as $46 \%$ of female headed households are living in poverty compared to $27 \%$ of male headed households (UNICEF, 2011). According to Statistics Botswana (2011), 52\% of households were male headed while $47.5 \%$ were female headed. An analysis of Botswana statistics since 1971 shows a decline in marriage rates from $47.1 \%$ among men to $18.8 \%$ in 2011 , 
and from $42.9 \%$ among women to $17.9 \%$ (Weekend post, 2015). This indicates the magnitude of unmarried women. This study was done in Gaborone the capital city of Botswana, including the surrounding areas, with an estimated population of 421,907 inhabitants as at 2011 census.

\section{The study:-}

The study on which this paper is based came about because of our wish to understand the challenges encountered by mumpreneurs. It is our conviction that this study is of significance as it has highlighted growth inhibitors or challenges towards mumpreneurship in Botswana. Significant effort in researching on mumpreneurship by other scholars is evident in the extant literature. Promoting women entrepreneurship requires more effort to be directed towards factors that hinder women entrepreneurs' success in Botswana (Aslam et al., 2013). To the best of our knowledge, there is a gap in mumpreneurship related literature especially a comparative study between home-based and out of home women run ventures in Botswana. In an effort to establish the challenges encountered by mumpreneurs in Botswana, this study avails an attempt to address the following research questions: What are the challenges faced by home based and out of home Botswana Mumpreneurs ventures? and What are the possible strategies to harness the challenges encountered by Botswana Mumpreneurs?

\section{Literature:-}

\section{Definition of Mumpreneurship:-}

Mumpreneurship is a new emerging trend that takes on the concept of entrepreneurship into family businesses and it is a part of female entrepreneurship (Nel et al., 2010). The Mumpreneurship concept is often associated with the objective of simultaneously being a good mother and a good business owner (Sheikh \& Yousafzai, 2015). Mumpreneurship is the creation of a new business venture by a woman who identifies as both a mother and a business woman, who is motivated primarily by achieving work life balance and picks an opportunity linked to the particular experience of having children (Richomme-Huet et al., 2013). Mumpreneurship constitutes a strong affirmative action in terms of their identity and dual role in society (Richomme-Huet et al., 2013). As most Mumpreneurs start business from home in an effort to work around children, which is in line with good motherhood as constructed by social norms of the society, it affects the performance and growth opportunities of the business run by these women (Sheikh \& Yousafzai, 2015).It is a form of entrepreneurship driven largely by the desire to achieve 'work-life harmony' through an identity orientation that blurs the boundary between the roles of 'mother' and "business woman" (Ekinsmyth, 2011). The mumpreneurship concept contradicts and challenges the assumption, prevalent in entrepreneurship literature, that economic growth is the raison d'être of entrepreneurship and it is an emergent phenomenon, which is yet to settle on a widely accepted definition or be researched from a social scientific point of view (Casteleijn-Osorno, 2014). Mumpreneurship can also be viewed as "a new business venture by a woman who identifies as both a mother and a business women, is motivated primarily by achieving work life balance and picks an opportunity linked to the particular experience of having children" (Richomme-Huet et al., 2013:267). Other scholars for example Jean and Forbes (2012) view mumpreneurs as women who have at least one child at the time of business startup and who is the owner of at least $50 \%$ of a business. Ekinsmyth (2011) defines mumpreneurs as individuals who discover and exploit new business opportunities within a social and geographical context that seeks to integrate the demands of motherhood and business-ownership. It follows therefore that mumpreneurs are women who start their own new 
ventures besides taking a role of being a mother (Nel et al., 2010). Richomme-Huet et al. (2013) mentioned characteristics of mumpreneurs that: they mostly live as a couple, are less educated, either have no previous work experience or they engage in activities different from their previous profession, for example, after having been a house wife or a salaried top manager in paid employment. Mumpreneurship definition is comprised of three main characteristics: identity (identity orientation that blurs the boundary between the role of mother and businesswomen), motivation (women are driven by desire to achieve work life harmony), and opportunity recognition (opportunity identification is linked to the particular experiences of having children) (Richomme-Huet et al., 2013).

\section{Challenges encountered by Mumpreneurs:-}

Challenges offered in this part of the study covers a broad spectrum of literature; some could be experienced by both home based and out of home entrepreneurs. Business success for women in Botswana is determined by the socio-cultural contexts (Ntseane, 2004). As Batswana women entrepreneurs aspire to grow, challenges confronting them, such as gender discrimination, lack of recognition for unregistered businesses, and discrimination in funding are prevalent (Ntseane, 2004). Self employment has been described as a dual pathway for women to a meaningful engagement with economic empowerment and the maintenance of family obligations (Lewis et al., 2015). Women reportedly possess traits and capabilities that enhance the possibility of success in the borderless cases (Ibarra, 2003). Batswana women are not powerless although the balance of power is overwhelmingly in the men's favor (Ntseane, 2004).

Ntseane (2004) observed that Botswana society appreciates the qualities of hard work, intelligence, courage and economic responsibilities shown by mumpreneurs but men still do not value women. Borderless career defines mothers transferring to self employment, as having a structured yet fluid form that embodies components that both bind and empower them in their life as entrepreneurs and mothers (Lewis et al., 2015). Scholars have observed that unlike the traditional belief that women are not the same as men, gender difference is no longer a barrier to run a business and become entrepreneurs (Hani et al., 2012).In some societies, women are the most disadvantaged group in terms of employment levels (Hani et al., 2012). Women are not only disadvantaged in terms of education, but also working women often get the discrimination salary that is usually lower than men (Hani et al., 2012). Scholars have observed and are convinced that women are equally able to identify and seize potential business opportunities (Hani et al., 2012).Regulatory institutions such as government, social welfare, education and tax can directly or/and indirectly affect operations of mumpreneurs (Sheikh \& Yousafzai, 2015).

Barriers to women entrepreneurs' development include: women enterprises have a bottleneck in securing financial support, environmental constraints hinder the spread of women business, women lack time to run their businesses, and they encounter intense competition (Hani et al., 2012). A United Nations (UN) (2000) women survey of six countries revealed that lack of capital is a critical hindrance in Botswana businesses start-up and during development stages (Gobagoba $\&$ Littrell, 2003). Other challenges encountered by Batswana mumpreneurs include insufficient management skills, lack of market information, limited information on appropriate technology development, acquisition of adequate premises, and difficulty in networking (Gobagoba \& Littrell, 2003).Other scholars came up with another combination of mumpreneurship challenges for example Nel et al. (2010) mentioned that mumpreneurs challenges include: starting ventures 
with lack of appropriate knowledge, resource constraints, stereotypes, balancing work and life, and limited networking. Five main challenges encountered by mumpreneurs as contributed by O'Gorman (2001) include: a) getting started with lack of business knowledge, b) resources constraints (distinct lack of finance as most mumpreneurs start their venture from their own savings, with minimum or zero external funding), c) women stereotype (as women and men have different perspectives regarding how they view the world, they react differently to given situations, they are more risk averse than men), d) balancing work and life (it is not easy to balance business with responsibilities of raising children, women in most societies still face traditional obligations regarding their role within the family and time to be spent at home), and e) fewer formal and informal networking opportunities as there are less opportunities to access information and social networks. Mumpreneurial ventures are heavily constrained by the institutional support in terms of child care provisions, training and financial support (Sheikh \& Yousafzai, 2015). On another note, women in business encounter problems like personnel, finance and marketing (Aslam et al., 2013). In a study done by Aslam et al. (2013) on Lebanese women entrepreneurs, it was found that problems encountered by entrepreneurs can be categorised into three categories: micro, meso and macro:

a. Micro challenges include opportunity identification, motivation, and performance and financing,

b. Meso problems include unwritten rules of conduct and behaviours based on norms, values, social roles, family values, religious beliefs and legitimacy of self employment while

c. Macro challenges refer to situations when mumpreneurs face legal environments and economic environmental problems. In a similar study done in Syria, it was found that mumpreneurs problems include limited access to finance, lack of knowledge and the knowhow to manage the business, flexibility, profitability analysis, quality controls, financial and technical management (Aslam et al., 2013). Building a shared vision for the future and reconciling inevitable conflicts become increasingly difficult, if not impossible (Ward, 1997).

Ward (1997) ranked the six most powerful challenges to women run business ventures as:

a. Maturing business life cycles and increasing competition.

b. Limited capital to fund both family needs and business growth needs.

c. Weak next-generation business leadership.

d. Entrepreneurial leadership's inflexibility and resistance to change.

e. Conflicts among sibling successors.

f. Incongruent family goals, values, and needs.

\section{Home based Businesses challenges:-}

Home based entrepreneurs encounter diverse challenges which include personal risk of failure, higher degree of personal commitment to the success of the firm, a lower degree of structure, predictability, and support as well as the need to perform multiple functions (Ward, 1997)

Family involvement has potential to generate internal pressure in an effort to apportion more time to meet family role demands (Parasuraman, Purohit, Godshalk \& Beutell, 1996). Due to the family role demands, most Batswana women home based owned businesses fail at introduction or initial stages of the business life cycle because business women fail to separate business resources from family assets (Ntseane, 2004). Research indicates that although there is freedom enjoyed by mumpreneurs working at home, they work long hours, experience work-family 
conflicts and are susceptible to stress reaction (Ntseane, 2004). Work-family conflict is a form of inter-role conflict in which the role pressures from the work and family domains are mutually incompatible in some respect (Parasuraman et al., 1996). Home based businesses fail due to the fact that they allow their ventures to be destroyed, due to the incompetence of venture owners/managers.

In majority family settings, Batswana women are expected to seek permission from their husbands, fathers, uncles, or even brothers to engage in business for example to travel long distances to go and sell or buy their business products (Ntseane, 2004).Home based businesses fail since, in majority of cases, owners or venture managers do not make the decisions needed to ensure the strength of their companies in an ever-changing, even more complex world (Ward, 2011). Growth is difficult for home based family owned businesses because of maturing markets, intensifying competition, and changing technology. Burdensome family responsibilities hinder the mumpreneurs ability to devote more time and expected energy to the business (Parasuraman et al., 1996). "Women entrepreneurs who operate at home view the freedom and flexibility offered by business ownership as facilitating the pursuit of active career and family roles concurrently"(Parasuraman et al., 1996:277).Main challenges faced by home based mumpreneurs are time or energy, role conflict and income or money problems (Aslam et al., 2013). The need for mumpreneurs to perform multiple business functions concurrently versus assorted demands from different stakeholders may result in experiencing role overload (Parasuraman et al., 1996). Aslam et al. (2013) also mentioned the hindrances to mumpreneurship growth as including absence of (technological knowhow) and corruption. Home based mumpreneurs also experience limited amount of government and institutional support and lack of support from family and society (Aslam et al., 2013).

Theoretical models of home based ventures dynamics and the related empirical research have demonstrated the importance of social support (spouse support) in influencing the wellbeing of mumpreneurs career (Parasuraman et al., 1996). Spouse support has been found to influence women's career choices, career priority and commitment to the business venture ( $\mathrm{Nel}$ et al., 2010; Parasuraman et al., 1996). There are two types of spouse support that can be offered to home based mumpreneurs: instrumental and informational support (Parasuraman et al., 1996)

Instrumental support refers to the potential help that could be accorded to mumpreneurs by their spouses for example maintenance of business premises, while informational or emotional support refers to information, advice, affirmation of affection and concern for the receiver's welfare support (Parasuraman et al., 1996). High levels of instrumental and informational support provided by one's spouse has potential to ease the burden of family role demands and this enables mumpreneurs to dedicate less time to the family role and more time to the work role (Parasuraman et al., 1996). However, it has been observed that home based mumpreneurs face social difficulties that is lack of family support, social constraints (for example gender inequality) and lack of entrepreneurial mentality, lack of education and skills and culturally oriented constraints (Aslam et al., 2013). In a study done in India, investigators found that most home based mumpreneurs lack supportive network, financial constraints, lack of skills and education (Aslam et al., 2013).Informational or emotional support has potential to enhance the mumpreneurs feeling of self efficacy and thereby decrease the severity of work-family conflicts (Parasuraman et al., 1996). 
Investment of additional time in the family role diminishes time available for the work role, thereby generating perceptions of family-to-work conflict (Berke, 2003). Also in another study done in Pakistan it was found that home based mumpreneurs are faced with gender neutral and gender related constraints which include: lack of support of family members, lack of established support network, access to capital, lack of business management skills and restrictive government regulations, lack of technical skills, gender neutral policies for example discriminatory attitudes by some bankers (Aslam et al., 2013). Berke (2003) mentioned that some stakeholders, for example government officials or bankers, associate home based businesses with lack of seriousness. According to Isidro (2015) home based businesses face a number of challenges including:

a. Separating work and family life

b. Not enough space (for operations, parking space for customers)

c. Not being taken seriously

d. Cannot do any work (due to local authority by laws and government regulations)

e. Lack of privacy

f. Strains in family relations

g. Working too much

h. Self disciple or self management

A study by Berke (2003) revealed that home based women businesses have to negotiate work and family using spatial behavioral, temporal, social and psychological strategies to manage internal and external temporal and spatial boundaries.

a. Spatial boundaries could include the actual physical area, equipment, and furnishings used primarily for work purposes (Berke, 2003)

b. Behavioral boundaries explore the overlap between domestic/personal life and work activities, for example, driving children to school; household members and others making demands on the home based mumpreneurs such as stopping by to talk; and receiving business calls "after work" or during meals" (Berke, 2003:525).

c. Temporal boundaries include the scheduling of activities, for example, hours of work done in one block, and rescheduling domestic and work activities, or using tools such as an answering machine to set temporal boundaries (Berke, 2003). Given that women are subject to patriarchal pressures that underlie their subordination in society, it is argued that being female will affect the experience of self-employment from initiation of the firm, to development of the enterprise through to the manner of daily management challenges.

\section{Mumpreneurship potential:-}

As much as entrepreneurial ventures are centered on the founder, there is an increasing awareness that the personal lives of entrepreneurs provide an intertwined effect of entrepreneurial ambitions, motivations, personalities, family and social networks (DeMartino \& Barbato, 2002). Ten tips to enhance success of mumpreneurs in both raising children as well as raising a new business are: passion and talents drive, do market research, go niche with their business plan-fit in with talent and skills, brand image-target the market for the products, support from spouse and family, should remember their objective(s), build their own networks, seek resources and knowledge, deliver every promise made, and managing business growth. There are organisations that offer help to mumpreneurs in Botswana for example Women in Business Association (WIBA), Local Enterprise Authority (LEA) and Department of Gender Affairs. 
Personal life, family and career orientations of mumpreneurs differ significantly from men run ventures (DeMartino \& Barbato, 2002). Female entrepreneurs are viewed as significant players in business as mentioned by GEM (2012) that they are now being viewed as new engines for sustainable economic growth. Family connections have significant influence on the resources mobilization and development of mumpreneurs ventures (Harris et al., 2008). The role of a partner and family in establishing entrepreneurial activities can influence success of mumpreneurs (Harris et al., 2008). To this end, social embeddedness of female entrepreneurship places greater importance on founders' social ties in identifying opportunities and mobilizing resources (Harris et al., 2008).

\section{Method:-}

A qualitative approach was adopted in which data was collected through semi-structured interviews. A purposeful sampling strategy which was complemented with some snowballing was applied. Empirical data for were collected from 13 selected Mumpreneurs (See Table 1) who reside in the Gaborone area. Data analysis was done through initial, intermediate and selective coding steps thereby developing themes. All 13 interviews were held from June to August 2015. One of the researchers had information about women run businesses hence she provided the initial list of five (5) potential participants, and thereafter we were advised of other business women by the participants.

\section{Data collection:-}

We collected data through semi-structured interviews with the identified 13 mumpreneurs (See Table 1). The interview guide was comprised of three sections: Section A: Personal data; Section B: Motivations and Strategies; and Section C: Business challenges. All interviews were done at the business premises of the selected participants. During interviews we were able to observe some non-verbal communications and business outlook that complemented the interviews. Also we were able to clarify some concepts that were not understood during the process.

Table 1: Profiles of Participants.

\begin{tabular}{|c|c|c|c|c|c|c|}
\hline Participants & Age range & Business line & Education & $\begin{array}{l}\text { Years in } \\
\text { business }\end{array}$ & $\begin{array}{l}\text { No. of } \\
\text { employees }\end{array}$ & $\begin{array}{l}\text { Home or Out of } \\
\text { Home }\end{array}$ \\
\hline 1 & $\begin{array}{l}31 \text { not } \\
\text { married }\end{array}$ & $\begin{array}{l}\text { Property and } \\
\text { construction }\end{array}$ & Degree & $\begin{array}{l}\text { Less than } 5 \\
\text { years }\end{array}$ & $\begin{array}{l}3 \& \text { more are } \\
\text { engaged } \\
\text { seasonally }\end{array}$ & $\begin{array}{l}\text { Both home based } \\
\text { and out of home }\end{array}$ \\
\hline 2 & $\begin{array}{l}32 \text { not } \\
\text { married }\end{array}$ & $\begin{array}{l}\text { Hire Out tents, } \\
\text { chairs, tables and } \\
\text { cutlery }\end{array}$ & Form 3 & $\begin{array}{l}\text { Less than } 5 \\
\text { years }\end{array}$ & 3 & Home based \\
\hline 3 & $\begin{array}{l}\text { More than } \\
62 \text { Married }\end{array}$ & $\begin{array}{l}\text { Bar and Bottle } \\
\text { Store, Butchery, } \\
\text { Restaurant and } \\
\text { Property }\end{array}$ & $\begin{array}{l}\text { Primary } \\
\text { (Standard 7) }\end{array}$ & $\begin{array}{l}\text { More than } \\
20 \text { years }\end{array}$ & 45 & Out of Home \\
\hline 4 & $\begin{array}{l}\text { More than } \\
53 \text { not } \\
\text { Married }\end{array}$ & Financial services & Masters & $\begin{array}{l}\text { Less than } 5 \\
\text { years }\end{array}$ & 12 & Out of Home \\
\hline 5 & $\begin{array}{l}\text { More than } \\
53 \text { Married }\end{array}$ & $\begin{array}{l}\text { Flower } \\
\text { arrangement shop }\end{array}$ & Diploma & $5-10$ years & 4 & $\begin{array}{l}\text { Both home based } \\
\text { and out of home }\end{array}$ \\
\hline 6 & $\begin{array}{l}37 \text { not } \\
\text { Married }\end{array}$ & $\begin{array}{l}\text { Financial } \\
\text { consultancy }\end{array}$ & Masters & $5-10$ years & 4 & Out of Home \\
\hline 7 & $\begin{array}{l}25 \text { not } \\
\text { married }\end{array}$ & Beauty Saloon & Form 5 & $\begin{array}{l}\text { Less than } 5 \\
\text { years }\end{array}$ & 8 & Out of Home \\
\hline
\end{tabular}




\begin{tabular}{|l|l|l|l|l|l|l|}
\hline 8 & 41 Married & $\begin{array}{l}\text { Transport and } \\
\text { Retailing }\end{array}$ & Diploma & $5-10$ years & 3 & Home based \\
\hline 9 & $\begin{array}{l}44 \text { not } \\
\text { Married }\end{array}$ & Food/local cuisine & Form 3 & $\begin{array}{l}\text { Less than 5 } \\
\text { years }\end{array}$ & 4 & Home based \\
\hline 10 & $\begin{array}{l}31 \text { not } \\
\text { Married }\end{array}$ & Law firm & $\begin{array}{l}\text { Bachelor's } \\
\text { degree }\end{array}$ & $5-10$ years & 8 & Out of Home \\
\hline 11 & $\begin{array}{l}41 \text { not } \\
\text { married }\end{array}$ & $\begin{array}{l}\text { Events } \\
\text { management }\end{array}$ & Diploma & $5-10$ years & 3 & Home based \\
\hline 12 & $\begin{array}{l}32 \text { not } \\
\text { Married }\end{array}$ & Training & Masters & $\begin{array}{l}\text { Less than 5 } \\
\text { years }\end{array}$ & 3 & Home based \\
\hline 13 & $\begin{array}{l}50 \text { not } \\
\text { Married }\end{array}$ & $\begin{array}{l}\text { Services } \\
\text { (gymnasium) }\end{array}$ & Masters & $5-10$ years & 12 & Out of Home \\
\hline
\end{tabular}

\section{Data analysis:-}

Data collected through the semi-structured interviews were analysed through several stages. The interview guide was translated into Setswana, Botswana official national language as we made it possible to do the interviews in English or Setswana. During the interview introductions, participants were required to choose their language preference whether English or Setswana. All interview stages incorporated processes of constant comparison, whereby data were continually compared and contrasted at each level of analysis; theoretical sampling, where emergent concepts and concerns arose from the data guided subsequent data collection; and theoretical sensitivity, which relied on the researcher's intuitive and interpretive analysis of the data (Birks \&Mills, 2010). Data analysis steps included initial coding and categorization of data (which was done through colour coding), (b) concurrent data generation or collection and analysis, intermediate coding and selective coding. The first stage was initial coding, "in which data was transcribed and broken down into units of meaning" (Charmaz, 2010, 2011 \& 2014); Bryant \&Charmaz, 2010). During initial coding, the researchers labeled and assigned units of meaning to incidents, actions, and events derived from the data. Intermediate coding occurred as the researchers began identifying preliminary themes and concepts emerging from the data (Barnett, 2012). In this stage we focused on the most significant and frequently occurring codes (Charmaz, 2011). Selective coding was the final stage in which we began merging concepts into thematic categories (Charmaz, 2010, 2011, 2014).

\section{Findings:-}

Findings of this study are presented according to the themes that were identified during data analysis. The identified mumpreneurship challenges were grouped into five themes: business related; government and institutional related; societal (society, self, family); financial and economic and ethical factors. Our findings are close to Aslam et al. (2013) assertions in that women entrepreneurs problems can be divided into three main categories: entrepreneurial/ business (securing finance, marketing and personnel), social/personal factors (lack of family support, lack of formal education and time constraints) and technical factors (non availability of raw materials, shortage of electricity and lack of skills). The study participants were distributed as: six (46\%) operate outside their homes, five (38\%) are home based while two (15\%) are both home based and are also out of home. All participants age ranged from 25 to 62 years, while their educational level ranged from primary school level to university masters degree. Ten (10) mumpreneurs are not married; while only three are married. All had been in business for at least three years and employed three or more workers at the time of the interview. The participants' business ventures shown on Table 1 are: property development and construction; hire out (tents, 
chairs, tables and cutlery); retailing (bar, butchery, restaurant); financial services; flower arrangement; financial consultancy; beauty salon; transport and retailing; food /local cuisine; law firm; events management; training consultancy and gymnasium). Our findings partly confirm Greene, Hart, Gatewood, Brush \& Carter (2013) assertion that most women engage in the traditionally viewed as women business which are: retailing, hospitality and services.

\section{Business related challenges:-}

All participants acknowledged the fact that competition is intense as their business lines are mainly dominated by male (Hani et al., 2012). Some of the competitors charge lower rates to win tenders but compromise quality- do sub-standard jobs which ultimately blow up on their faces. Some competitors masquerade as customers to get business intelligence. There are price wars as a result of intense competition. In an effort to emphasise the magnitude of competition Participants 7, 11 and 12 said:

"The magnitude of competition is almost like an overtraded opportunity, the business has evolved as some offer more contemporary products -well designed and modern tents, exclusive chairs, and I am constrained by capital to upscale”

"Competition is fierce - we have unscrupulous competitors - they manage by providing some purported "good" customer service"

"Some competitors undercut prices to retain customers- but in our business we decided to remain professionals instead of fighting based on pricing”

Though competition is necessary, concern is that some competitors use unethical strategies to retain customers and discourage them from switching service providers. Mumpreneurs are encountering unfair competition practices from the males run ventures, as they are already established and more so they have more networking platforms through social gatherings like clubs, bars, sporting activities where most women do not have time for. Participant 1 was of the view that:

"Property and construction is a male dominated industry, some of the competitors charge lower rates to win tenders but compromise quality, they do sub-standard jobs which ultimately blow up on their faces"

Mumpreneurs mentioned that their survival in business is due to their offerings. There is resistance by most customers to change their traditional service providers to switch over to mumpreneurs as they are loyal to their old service providers.

Some mumpreneurs are encountering challenges related to their raw materials since they rely heavily on imports. For example Participant 5 mentioned that:

"Lack of suppliers of raw materials domestically led to ultimately discontinuation of my decorative candle making aspect of the business" 
And the participant further said:

"It is becoming expensive to obtain raw materials from South Africa. It is expensive to obtain flowers and roses from South Africa as flowers are couriered and because of the hot weather sometimes the flowers wither. There are no local suppliers or growers of flowers domesticallydue to weather challenges-very hot".

Competition is intense because of mushrooming of small firms. Ten of the mumpreneurs acknowledged that they survive through provision of good service to clients for example Participant 10 said

"..we do not compete based on price but on the quality of service-that's how I outcompete other competitors"; Mumpreneurs are geared towards provision of value for money for example Participant 1 said

\section{"If the client wants my services, they have to pay appropriately for the good service".}

Some local businesses (potential customers) prefer to get services from South African companies and overlook local companies; there is a perception that local services for example training, event managers are inferior. With the advent of intense competition mumpreneurs have to provide unique products and not engage in price wars. Mumpreneurs inform their clientele about the uniqueness of their products offering. Some mumpreneurs have built loyal clientele who value good service.

Mumpreneurs who operate their businesses out of home highlighted challenges that appeared unique to them. Those who operate out of home experience high rentals and at times they may get some office or industrial space at places which are not ideal for their businesses, for example Participant 8 mentioned that:

"Office space is very expensive, I once rented office space but had to move to home operation because renting space was too expensive".

Five home based participants (participants 2, 8, 9, 11 and 12) observed little knowledge by other organisations (their potential customers) as regards their businesses location and offerings. Participants also mentioned that some companies prefer internally orginised events instead of outsourcing. Most organisations prefer the already established businesses; instead of engaging upcoming companies, for example, Participant 11 acknowledged that her business is experiencing this form of challenge. Home based businesses lack publicity, as they are not using all advertising platforms because they are expensive. Having a home based venture requires one who is able to perform both family and business tasks in a balanced manner, without compromising the other. Mumpreneurs have time management challenges; they are chances of working long hours as they try to balance both categories of demands (business and family roles). Home based ventures are isolated in the residential areas and that brings challenges in relation to networking, and some customers may have challenges to have confidence in the home based venture as mentioned by Participants 11 and 12 that: 
"We are isolated from the industrial area where most commercial activities are done, some customers lack confidence in home based businesses"

All home based mumpreneurs expressed challenges related to dual responsibilities of being a mother and a business manager as it compromises on efficiency and effectiveness. Mumpreneurs at times encounter challenges in meeting customers' deadlines, meeting business goals and operational targets due the dual responsibilities. Mumpreneurs are characterized by integrating specific contexts such as motherhood for example household characteristics and family context and meso/micro environmental aspects such as expectations of society, cultural norms, intermediate structures and institutions (Richomme-Huet et al., 2013).

\section{Government and institutional challenges:-}

There are several regulations and bylaws hindering smooth operations of businesses for example, constraints in terms of opening and closing hours for certain businesses (certain restrictions have been imposed on businesses selling times for example retailers) (Sheikh \& Yousafzai, 2015). Building regulations are a constraint to both home based and out of home ventures) as numerous requirements are needed by local authorities, for example, Participant 1 highlighted that she:

"submitted plans to build the first thatched warehouse in the country, but I was denied growth by local authorities due to local buildings regulations which required that adequate space be provided for entry and exit of big delivery trucks".

Participant 9 mentioned that

"I would like to have a permanent structure for selling purposes but the local authorities are preventing me because of government regulations"

It was generally observed that there is lack of support for businesses owned by locals especially women led companies; there is a tendency to support foreign owned businesses at the expense of locally owned ones. In some sectors mumpreneurs observed lack of support for example Participant 1 mentioned that:

"Thatching is not regulated-hence there are no standards that contractors are expected to adhere to, hence there are no quality standards."

Societal (society, self, family) factors:-

To combine social obligations and business commitments has been mentioned as one of the leading challenges for example participant 2 said:

"Being a woman and a single mum I have to take care of children, when I'm tendering for my children, my male counterparts are a step ahead. They have ample time to go to bars and other entertainment places to network with their male counterparts while I'm still tendering for my children. This gives them an edge over businesses run by mums".

Mums are compelled to balance between running a business and taking care of the children as well as taking care of household chores. Mumpreneurship could also be viewed as a necessity entrepreneurship as it is based both in the necessity of producing an income and the necessity of 
achieving a work life balance (Richomme-Huet et al., 2013). Participants also highlighted the fact that local employees "Batswana are lazy" as they are not as hard working and committed as foreign employees. Some Batswana employees are more into having fun than being committed to working especially that they know that if they do not work they can resort to the extended family for support hence they lack incentive to work hard enough as pointed out by Participant 8 :

"Some Batswana have no dreams of going somewhere in life, they always have excuses for not being at work and they claim to know their rights as well".

All participants subscribed to the notion that local employees reluctance to work hard is based on the fact that they think that they will be enriching business owners. Some Batswana employees are not comfortable to work under pressure, and they easily abscond from work without prior permission. Achieving a balance between raising children/social activities and work is a big challenge (Richomme-Huet et al., 2013), for example participant 11 mentioned that

"As a self employed woman, I have to sacrifice a lot more than employed woman, working extra hours, entertaining visitors, participating in social functions, while at the same time making sure that employees are well supervised"

Sometimes male entrepreneurs have better networking opportunities than their female counterparts as they have more extra time like sporting, clubbing where they can establish some networks and collaborations. Cultural values frame successful business strategies as Botswana women engaged in business are characterized by non-competitive networks, collective management strategies and informal cross-border trade as main pillars of sustainable business success (Ntseane, 2004).The main observed factors that are likely to impede success of Botswana mumpreneurs are patriarchal control and cultural pressure that counter good business sense (Ntseane, 2004).

It was observed that not all family members are supportive of businesses established by mumpreneurs. Children and spouses can be detrimental to the growth of business. For example, Participant 3 shared with us that:

"I got into trucking business with my husband (was a marriage of convenience I just wanted a partner to keep my company) but the husband had no business background. My husband was the manager of the transport business-Unfortunately he mismanaged it and it went under. I paid off the transport business debt from other businesses income. I bailed out the business and decided thereafter for the husband to start his own business alone"

Also Participant 8 shared with us that

"I once passed through some challenging moments as I once separated with my husband as he went to stay with another woman. I was pregnant when my husband left; subsequently I gave birth to my baby and thereafter I realized that life was difficult being alone with children responsibilities. That dark moment led me to start my business at home"

The major challenge peculiar to home based mumpreneurs was that of disturbance by children, other family members, and other people who visit mumpreneurs without prior knowledge that 
they will be busy. Within the Botswana culture, women are considered to be the social leaders, hence are expected to be more active in most social/cultural functions for example: society expect them to participate in food preparation, washing dishes, serve meals during functions like funerals, weddings, marriage ceremonies. This assertion has been confirmed by (Ntseane, 2004) who found that most Batswana women exemplify other African societies, patriarchy reigns as women who engage in businesses are entrepreneurs and domestic servants for their families and society. Mumpreneurs contributed that the challenges are worse with those who are not married mothers as they assume mother and father responsibilities. Women tend not to support one another but prefer to support male owned businesses.

Participant 9 was of the view that men seem to be more successful in securing funding than women even though there are no restrictions in terms of access to funding.

\section{Financial challenges:-}

All participants showed discontentment on the nature and processes involved in an attempt to secure funding for their businesses (Hani et al., 2012). Almost all financial related challenges are common to both home based and out of home based ventures. Businesses that import raw materials or some business inputs, have observed that the costs of inputs for example flowers, cooking gas, gym equipment are in most cases very high for their capability. There is generally an outcry by mumpreneurs as highlighted by Participant 7 that:

"as regards to access to financial support, financiers are not convinced enough to finance the business ideas initiated by women"

Some funders lack trust in women initiated business ideas; this is despite the fact that government has initiated a number of funding opportunities for women empowerment. Six of the participants highlighted challenges related to cash flow when running the business for example,

Participant 3 had this to say:

"My husband used business proceeds to finance dubious "businesses" and was flashy with ladies hence -we agreed to separate businesses. Unfortunately, my husband's businesses have not been successful. He obtained a loan by using our residential property as collateral but as has become the norm, the businesses went under and the bank is in the process of repossessing and selling the property to clear the debt"

All participants mentioned that securing finance is a challenge to all of them, and this affects their businesses at all stages of venture life cycle. However, scarcity of financial support has more impact on the start-ups as in majority cases, it is difficult to save significant amount to start a business. Start-up mumpreneurs are said to lack collateral security and track record. Cash flow management challenges are prevalent to all mumpreneurs ventures. Participant 9 observed that

"the tendency is that government supports big businesses than small and medium sized businesses for example, for government tenders, there are high fees required for tendering and this deters small businesses from participating in big tenders hence hampering their growth" 
Access to finance is a challenge especially for upcoming/young businesses and for those who operate in rented premises. So issues of access to finance should be facilitated in order for businesses run by mums to succeed. Mums need to grow their businesses in order to take care of their families. Mumpreneurs who operate outside home (Participants 1, 3, 4, 5, 6, 7, 10 and 13) concurred on the fact that cost of utilities are high, and this leads to increased cost of doing business. Also all those operating out of home experience high rentals-leading to cash flow challenges.

\section{Ethical challenges:-}

Almost all mumpreneurs perceived some "cancerous" scenario in Botswana business environment. Although all participants observed that there is serious level of corruption, Participant 1 narrated that:

"Corruption and solicitation of bribes is rampart in the business environment".

Twelve of the businesses except Participant 5 are not registered with Public Procurement And Disposal Board (PPADB) because they either fear of solicitation of bribes by the responsible officers or they cannot afford the anticipated bribes. Corrupt practices are said to be more prevalent in construction and related industries. Mumpreneurs clients are not willing to pay for mobilization to facilitate discharge of the tender, and this makes it difficult for mumpreneurs to implement projects successfully.

In some cases, mumpreneurs experience some pilferage of stock and cash and this is common when the owner is away as observed by Participant 7 that:

"..we get feedback from regular customers that they came to the saloon for some service and will not find a corresponding entry for that particular customer in the daily records"

As regards business premises, mumpreneurs are prone to some unfair practices by the property landlords as they usually offer short-term lease agreements, and sometimes they terminate the lease agreement when they see that the business is flourishing (done out of jealousy). Also some landlords review rentals amounts as and when they wish. This led Participants 11 and 12 to resort to continuing operating at home regardless of the challenges experienced by home based ventures.

\section{Possible strategies for mumpreneurship growth:-}

In view of the observed challenges, mumpreneurs suggested several recommendations which will be discussed in relation to the identified themes namely business environment, government and institutional, societal, financial and economic and ethical.

\section{Business related strategies:-}

All participants felt that knowledge sharing platforms should be provided where successful and already established business persons are given opportunities to present some motivational talks sharing success stories. Women need networking opportunities to help and encourage each other. Our finding is in sync with Ntseane, (2004:42) who mentioned that: 
"Through collaborative and reciprocal competitive networks small businesswomen in Botswana have a chance of success".

According to participants' views, these platforms will also support mumpreneurs in many other business activities like marketing and purchasing.

\section{Government and institutional strategies:-}

Participants were of the view that the Botswana government should relax the immigration laws to allow for employment of foreign workers as it would go a long way in facilitating access to skilled labor. This will facilitate growth of the business especially that foreign workers are more committed and serious minded than young local employees (restrictions on employment of noncitizens employees is posing a challenge to local businesses especially where skilled and experienced workers are needed.) This challenge/constraint thwarts growth prospects of businesses locally. Most participants recommended that there is need to establish a business hub that supports upcoming businesses that may not initially be able to afford full time professionals such as accountants, legal services, marketing, coaching. The hub will essentially provide all business support services to upcoming businesses for a fee. In elaboration of that view, Participant 11 was of the view that:

“..provision of one stop facility for businesses who cannot afford to have full time professional employees to perform functions such as IT, finance, sales and marketing will be advantageous"

On another note, it was recommended that the government in collaboration with the private sector should consider developing export markets/expansion for the upcoming businesses as this will attract foreign currency to the economy. Since the government is a significant customer, participants suggested the need for the government to provide a tender quota system for businesses run by women as is the case with youth businesses. Strategies towards inculcating entrepreneurship skills at a young age (for example at primary education level) should be adopted. Networking and/or collaborations initiatives can be enhanced by the government in which assistance in finding partners to facilitate growth-in terms of market penetration and expansion of market offerings. Mumpreneurs are advocating for an equal support from the government, unlike the current situation where there is tendency to support youth businesses who create unhealthy price wars by charging unsustainably and unbelievably low prices.

\section{Financial related strategies:-}

Since financial management is a challenge that confronts almost all mumpreneurs, it was recommended that funders should provide training in financial management and financial discipline skills. Building a reputation or track record with financial institutions is strategic as it can facilitate growth of the business through funding opportunities. Not all mumpreneurs exhibit sound financial management as observed by Participant 9 that:

"some women who operate businesses do not even have bank accounts hence they are hampered from growing their businesses through debt financing".

In view of financial management skills, participants recommended that support for women owned businesses should be provided by both government and private sector levels. There is 
need for tailor make financial packages to be designed for women owned businesses as mentioned by Participant 10 that:

"Citizen Entrepreneurial Development Agency (CEDA) should have some funding product for women owned businesses much as they have for young farmers".

Also participants were of the view that the conditions provided by funders are too stringent, and they suggested that government and other associations should lobby for manageable terms to be extended to mumpreneurs. The need for knowledge sharing cannot be over emphasised, as mentorship and training in management functions like finance, marketing, production and many others should be a continuous activity in an effort to ensure sustainability of businesses. Mumpreneurs commented that business support institutions like Local Enterprises Authority (LEA) are narrowly focused as this was confirmed by Participant 1 who shared with the investigators that:

"I once requested assistance from LEA, and I was declined due to my business line of thatching which they said it is not part of the business lines they support"

Participants suggested that there has to be a special fund to finance women owned businesses as much as there is Youth fund and Young farmers' fund. There are delays in accessing funding, and mumpreneurs suggested the need to improve the turnaround time. It was also suggested that mumpreneurs should separate home finances from business finances. Keeping proper and up to date financial records of the business should always be encouraged among entrepreneurs; otherwise the business will be beset by cash flow challenges

\section{Ethical related strategies:-}

Mumpreneurs observed that Botswana Government has good initiatives but administrators are a challenge, they induce artificial bottlenecks to those who need government support.

Participant 12 narrated that

"..so government needs to double its efforts to deal with corruption issues more aggressively"

This view was also supported by Participant 2 who said:

"There has to be transparency in government and the business sector-to ensure that funding is granted to businesswomen based on ability and capability instead of whom one knows or what one can offer-(Weed out corruption)"

\section{Conclusion:-}

On the basis of analysis of data and discussion of the study findings it is concluded that majority of mumpreneurs in Botswana face similar problems. Our study established that mumpreneurs whether operating at home or out of home face five main challenges related to: business environment, government and institutional, societal (society, self, family), financial and ethical.

Mumpreneurs who operate their businesses out of home highlighted challenges that appeared unique to them: 
* Experience high rentals and at times they may get some office or industrial space at places which are not ideal for their businesses.

* Home based mumpreneurs mentioned that there is little knowledge of their existence by other organisations (their potential customers) as regards their businesses location and offerings

* Home based businesses lack publicity, as they are not using potential promotional channels platforms since they are expensive.

* Having a home based venture requires one who is able to perform both family and business tasks in a balanced manner, without compromising the other.

* Mumpreneurs have time management challenges; they are chances of working long hours as they try to balance both categories of demands (business and family roles).

* Home based venture are isolated as they are located in residential areas and that brings challenges in relation to networking, and some customers may have challenges to have confidence in a home based venture.

\section{Limitations of the study and Future research}

Just like most other research projects, this study experienced some limitations which could be addressed in future related researches. The study was done in Gaborone the capital city of Botswana and the surrounding areas. Researchers used a sample of thirteen (13) mumpreneurs as we had had arrived at some data saturation stage. Complementing this qualitative research with a quantitative approach will increase the sample size thereby enhancing this research findings potential to be generalisable. Our findings reveal that Batswana women entrepreneurs encounter several challenges that hinder their business sustainability. Since Batswana women businesses encountering diverse challenges, research could be done aimed at establishing business traits possessed by other nationalities who seem to have successfully run businesses with longer life cycles. During the interviews, mumpreneurs demonstrated signs of being loaded with diverse stresses which are socially and business related. Research towards the need to establish business counseling related services could play a significant role as participants behaved as if our presence offered them an opportunity to outpour their problems. Botswana mumpreneurs don't have a platform to share their challenges, they just suffer in silence. Mumpreneurs have shown significant potential, but are limited by social and business related challenges that may be addressed by a longitudinal investigation.

\section{Reference:-}

1. Allen, I. E., Elam, A., Langowitz, N., \& Dean, M. (2007).Global entrepreneurship monitor. 2006 Report on Women and Entrepreneurship.

2. Aslam, S., Latif, M., \& Aslam, M. W. (2013). Problems Faced by Women Entrepreneurs and Their Impact on Working Efficiency of Women in Pakistan. Middle-East Journal of Scientific Research, 18(8), 1204-1215.

3. Barnett, R. (2012). Learning for an unknown future. Higher Education Research \& Development, 31(1), 65-77.

4. Berke, D. L. (2003). Coming Home Again the Challenges and Rewards of Home-Based SelfEmployment. Journal of Family Issues, 24(4), 513-546.

5. Birks, M., \& Mills, B. (2010). Grounded theory: A practical guide, Sage publications, ooks.google.co.bw/books 
6. Bryant, A., \& Charmaz, K. (2010). Grounded theory in historical perspective: An epistemological account. Handbook of grounded theory, 31-57.

7. Casteleijn-Osorno, R. (2014). Comparing sense-making of identities of mumpreneurs in Malta and Finland

8. Charmaz, K. (2010). Grounded theory as an emergent method. Handbook of Emergent methods

9. Charmaz, K. (2011). Grounded theory methods in social justice research. The Sage handbook of qualitative research

10. Charmaz, K. (2014). Constructing grounded theory. Sage.

11. DeMartino, R., \& Barbato, R. (2002).An analysis of the motivational factors of intending entrepreneurs.

12. Ekinsmyth, C. (2011).Challenging the boundaries of entrepreneurship: The spatialities and practices of UK 'Mumpreneurs'. Geoforum, 42(1), 104-114.

13. Global Entrepreneurship Monitor. (2007).South Africa report

14. Global Entrepreneurship Monitor. (2012). African Entrepreneurship, Sub-Saharan African Regional report.

15. Gobagoba, M. R., \& Littrell, M. A. (2003).Profiling micro apparel enterprises in Botswana: motivations, practices, challenges, and success. Clothing and Textiles Research Journal, 21(3), 130-141.

16. Greene, P. G., Hart, M. M., Gatewood, E. J., Brush, C. G., \& Carter, N. M. (2003). Women entrepreneurs: Moving front and center: An overview of research and theory. Coleman White Paper Series, 3, 1-47.

17. Hani, U., Rachmania, I. N., Setyaningsih, S., \& Putri, R. C. (2012). Patterns of Indonesian Women Entrepreneurship. Procedia Economics and Finance, 4, 274-285.

18. Harris, C., Morrison, R., Ho, M., \& Lewis, K. (2008). Mumpreneurs: mothers in the business of babies. In 22nd Annual Australian and New Zealand Academy of Management Conference (ANZAM) (pp. 2-5).

19. Ibarra, H. (1993). Personal networks of women and minorities in management: A conceptual framework. Academy of management Review, 18(1), 56-87.

20. Isidro (2015) http://www.powerhomebiz.com/working-from-home/challenges/problems-ofworking-at-home.htm

21. Jean, M., \& Forbes, C. S. (2012). An Exploration of the Motivations and Expectation Gaps of Mumpreneurs. Journal of Business Diversity, 12(2), 112-130.

22. Lewis, K. V., Harris, C., Morrison, R., \& Ho, M. (2015). The entrepreneurship-motherhood nexus: A longitudinal investigation from a boundaryless career perspective. Career Development International, 20(1), 21-37.

23. Marlow, S. (1997). Self-employed women-new opportunities, old challenges? Entrepreneurship \& Regional Development, 9(3), 199-210.

24. Modisane, R. (ny). www.stanbicbank.co.bw

25. Monitor, G. E. (2007). 2007 Executive Report

26. Nel, P., Maritz, A., \& Thongprovati, O. (2010). Motherhood and entrepreneurship: the mumpreneurs phenomenon. International Journal of Organizational Innovation, 3(1), 6-34.

27. Ntseane, P. (2004).Being a female entrepreneur in Botswana: cultures, values, strategies for success. Gender \& Development, 12(2), 37-43.

28. O'Gorman, C. (2001).The sustainability of growth in small-and medium-sized enterprises. International Journal of Entrepreneurial Behavior \& Research, 7(2), 60-75. 
29. Parasuraman, S., Purohit, Y. S., Godshalk, V. M., \& Beutell, N. J. (1996).Work and family variables, entrepreneurial career success, and psychological well-being. Journal of Vocational Behavior, 48(3), 275-300.

30. Richomme-Huet, K., Vial, V., \& d'Andria, A. (2013). Mumpreneurship: A new concept for an old phenomenon? International Journal of Entrepreneurship and Small Business 25, 19(2), 251-275.

31. Schumpeter, J. A. (1934). The theory of economic development: An inquiry into profits, capital, credit, interest, and the business cycle, (55). Transaction publishers.

32. Sheikh, S., \& Yousafzai, S. (2015). Institutional embeddedness of Mumpreneurship in the UK: A careers narrative approach

33. Statistics Botswana. (2013). Population and housing census 2011 dissemination seminar

34. Botswana, S. (2011). Botswana population and housing census. Alphabeticall index of Districts.

35. UNICEF. (2011). Botswana Annual Report

36. Ward, J. L. (1997).Growing the family business: Special challenges and best practices. Family Business Review, 10(4), 323-337.

37. Weekend post. (2015). www.weekendpost.co.bw/ 